"Pengaruh Asam Retinoat \& Kelainan Bawaan Eksternal pada Janin di Masa Kehamilan"

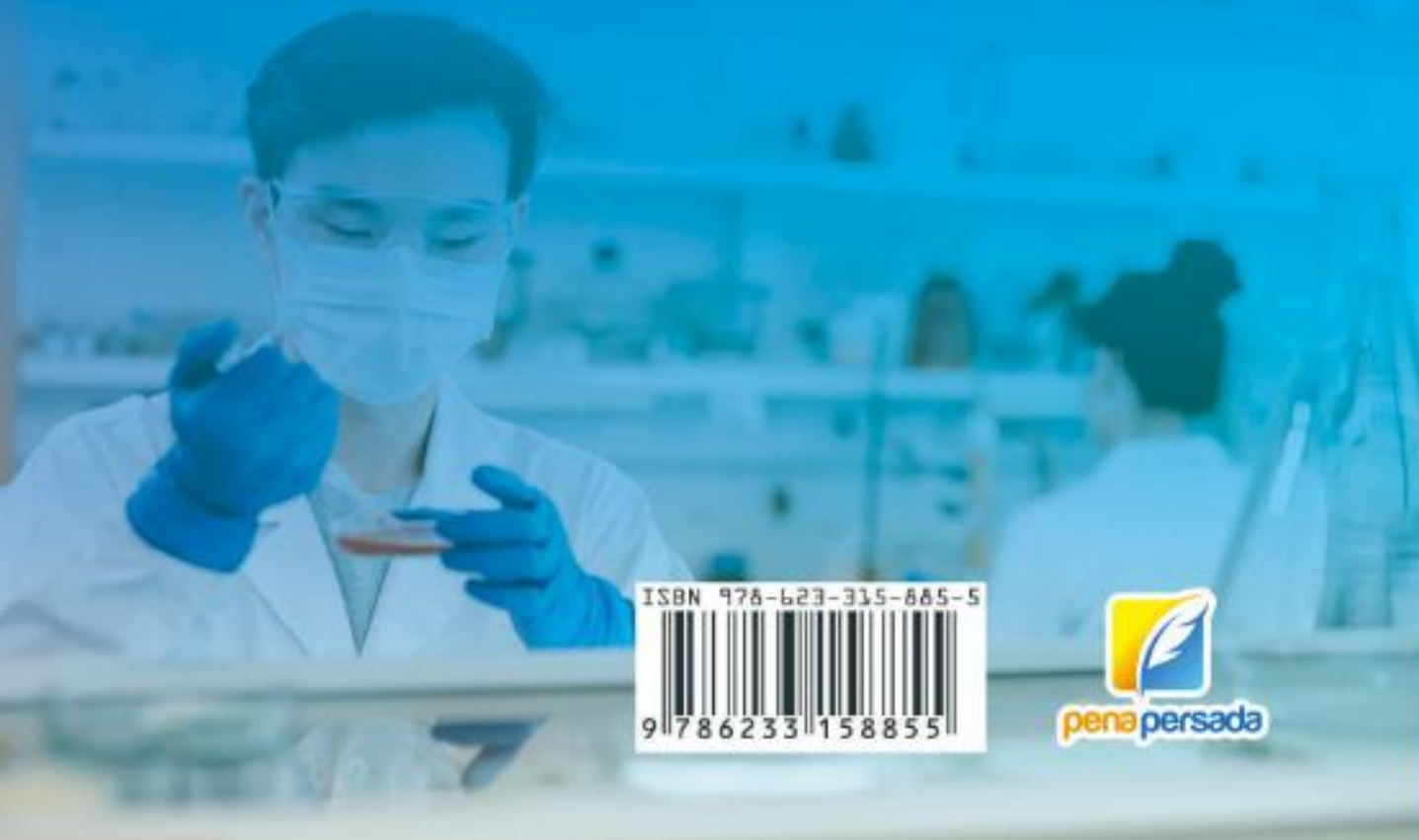




\section{PENGARUH ASAM RETINOAT \\ DAN KELAINAN BAWAAN EKSTERNAL PADA JANIN DI MASA KEHAMILAN}

TERESIA RETNO PUSPITA DEWI

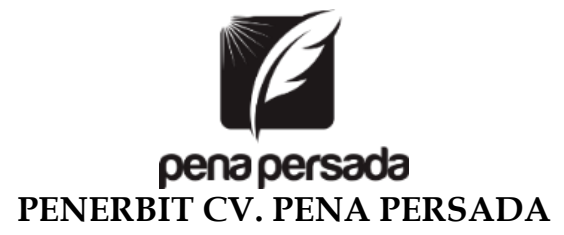




\title{
PENGARUH ASAM RETINOAT \\ DAN KELAINAN BAWAAN EKSTERNAL \\ PADA JANIN DI MASA KEHAMILAN
}

\author{
Penulis: \\ Teresia Retno Puspita Dewi
}

ISBN : 978-623-315-885-5

Editor:

Fitriani Dwi Ramadhani

Design Cover :

Arsyie Kania Rakhma

Layout :

Nofendy Ardyanto

Penerbit CV. Pena Persada

Redaksi :

Jl. Gerilya No. 292 Purwokerto Selatan, Kab. Banyumas

Jawa Tengah

Email : penerbit.penapersada@gmail.com

Website : penapersada.com Phone : (0281) 7771388

Anggota IKAPI

All right reserved

Cetakan pertama : 2021

Hak Cipta dilindungi oleh undang-undang. Dilarang memperbanyak karya tulis ini dalam bentuk apapun tanpa izin penerbit 


\section{KATA PENGANTAR}

Puji syukur saya panjatkan kepada Tuhan Yang Maha Esa, karena atas berkat dan rahmat-Nya, saya dapat menyelesaikan buku ini. Penulisan buku merupakan buah karya dari pemikiran penulis yang diberi judul " Pengaruh Asam Retinoat Dan Kelainan Bawaan Eksternal Pada Janin di masa Kehamilan ". Saya menyadari bahwa tanpa bantuan dan bimbingan dari Professor. Win Darmanto, MSi., Ph D, Dr. Bambang Poernomo S, drh., MS serta berbagai pihak sangatlah sulit bagi saya untuk menyelesaikan karya ini. Oleh karena itu, saya mengucapkan banyak terima kasih pada semua pihak yang telah membantu penyusunan buku ini. Sehingga buku ini bisa hadir di hadapan pembaca. Kajian dalam buku ini bertujuan untuk mengetahui masa organogenesis merupakan masa penting untuk perkembangan normal dari sebagian besar organ dan sistem organ. Apabila embrio yang sedang berkembang terpapar agensia toksik maka ada peluang proses perkembangannya menjadi terganggu. Asam Retinoat merupakan salah satu bentuk vitamin A yang larut lemak, masih banyak digunakan untuk pengobatan penyakit kulit. Asam retinoat ini bersifat teratogen karena sifat metabolisme vitamin larut lemak diekskresikan sangat lambat dari tubuh, terakumulasi dalam tubuh, ditimbun dijaringan sehingga meracuni tubuh, dan dosis berlebih menimbulkan efek toksik. Penggunaan asam retinoat berlebih pada ibu hamil trimester pertama bersifat irreversibel. Senyawa yang bersifat lipofilik cenderung berdifusi dengan mudah melintasi plasenta, masuk sirkulasi janin, dapat memberikan dampak negatif terhadap perkembangan bayi dalam kandungannya, berupa kegagalan kehamilan serta terjadinya kelainan organ dalam bentuk kelainan kongenital ringan, berat bahkan kematian

Penulis menyadari bahwa buku ini masih jauh dari kesempurnaan. Oleh karena itu kritik dan saran yang membangun sangat dibutuhkan guna penyempurnaan buku ini. Akhir kata saya berharap Tuhan Yang Maha Esa berkenan membalas segala kebaikan semua pihak yang telah membantu. Semoga buku ini akan membawa manfaat bagi pengembangan ilmu kesehatan. 


\section{DAFTAR ISI}

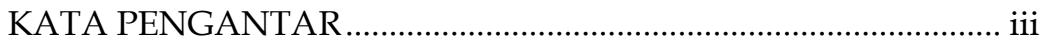

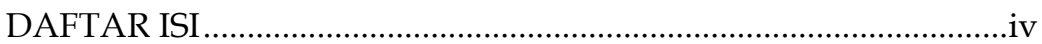

BAB 1 PEMBERIAN ASAM RETINOAT PADA INDUK MENCIT 1

A. Pemberian Vitamin ............................................................ 1

BAB 2 TINJAUAN UMUM ASAM RETINOAT ................................. 4

A. Asam Retinoat ...................................................................

1. Absorpsi, Transportasi dan Metabolisme Asam

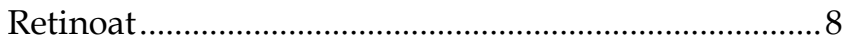

B. Organogenesis Dan Teratogenitas ........................................15

1. Klasifikasi Mencit (Mus musculus) ..................................15

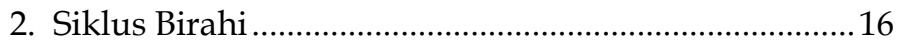

3. Perkembangan Normal Mencit .....................................17

4. Tingkat Organogenesis pada Perkembangan Embrio

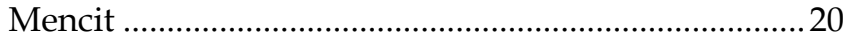

5. Kelainan Kongenital Eksternal........................................23

6. Prinsip - Prinsip Teratogenitas ....................................... 24

C. Hubungan Teratogenitas Asam Retinoat Dengan Masa

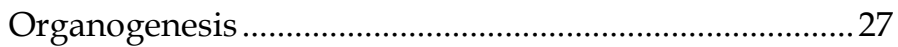

BAB 3 KERANGKA KONSEPTUAL DAN HIPOTESIS....................39

A. Kerangka Konseptual Kajian..............................................39

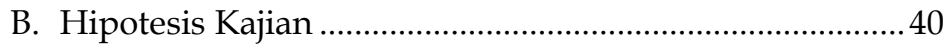

BAB 4 MATERI DAN METODE KAJIAN ........................................ 41

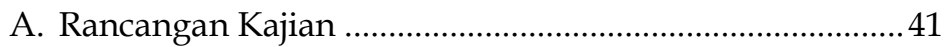

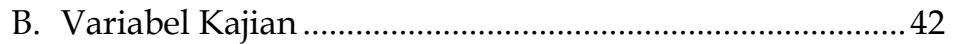

1. Klasifikasi Variabel .......................................................... 42

2. Definisi Operasional Variabel ......................................... 43

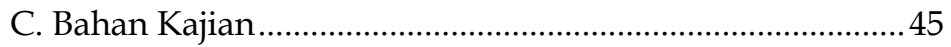

1. Hewan Coba .................................................................. 45

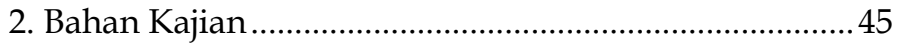

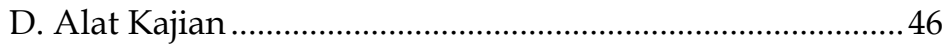

1. Alat Pemeliharaan Mencit dan Perlakuan :...................46

2. Prosedur Penelitian .......................................................... 46

3. Prosedur Pengambilan Atau Pengumpulan Data .....47

4. Proses Penimbangan dan Mengawinkan Mencit...... 47 
5. Perlakuan dan Pengelompokkan Hewan Percobaan 49

6. Cara Pengumpulan Dan Analisis Data .51

BAB 5 HASIL DAN ANALISIS KAJIAN EFEK PEMBERIAN

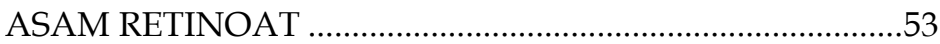

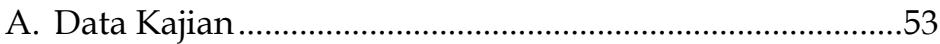

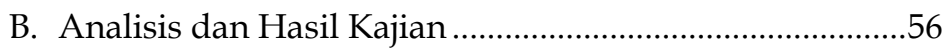

1. Hasil Analisis Uji Normalitas ......................................56

2. Hasil Uji Homogenitas Data ...........................................57

3. Hasil Uji t-test Dua Sampel Bebas ...............................57

4. Analisis Hasil Reproduksi...............................................58

5. Kelainan Bawaan Eksternal ...........................................60

BAB 6 PEMBAHASAN PEMBERIAN ASAM RETINOAT PADA

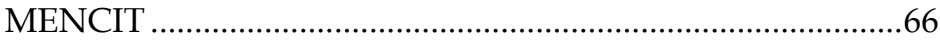

A. Hasil Penelitian Setelah Diberi Minyak Wijen dan

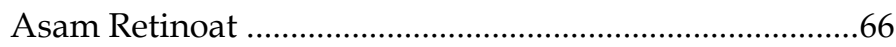

1. Uji normalitas dan homogenitas data ..........................66

2. Pengaruh Pemberian Asam Retinoat Terhadap Hasil Reproduksi Induk Mencit .67

3. Pengaruh Asam retinoat pada Morfologi Fetus

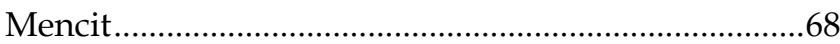

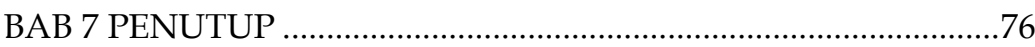

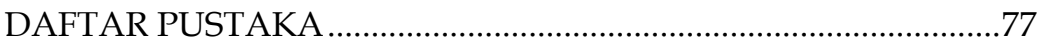




\section{PENGARUH ASAM RETINOAT DAN KELAINAN BAWAAN EKSTERNAL PADA JANIN DI MASA KEHAMILAN}




\section{BAB 1 \\ PEMBERIAN ASAM RETINOAT PADA INDUK MENCIT}

\section{A. Pemberian Vitamin}

Vitamin merupakan senyawa organik yang dibutuhkan dalam jumlah kecil untuk berbagai fungsi biokimiawi yang umumnya tidak disintesis oleh tubuh sehingga harus dipasok dari makanan. Pemasokan vitamin yang larut dalam lemak ini memerlukan absorbsi lemak yang normal agar vitamin tersebut dapat diabsorbsi secara efisien. Begitu diabsorbsi molekul vitamin tersebut harus diangkut dalam darah yaitu oleh lipoprotein atau protein pengikat yang spesifik (Joyce, 1996).

Vitamin A merupakan salah satu vitamin yang larut dalam lemak. Vitamin A terdapat dalam beberapa bentuk misalnya retinal, asam retinoat (tretinoin / all-trans-asam retinoat, isotretinoin / 13-cis asam-retinoat) dan retinol. Vitamin A diperlukan untuk banyak proses biokimiawi, membantu pembentukkan pigmen penglihatan, untuk pertumbuhan dan perkembangan tulang, serta meningkatkan integritas (keutuhan) jaringan mukosa dan epitel (Murray, 2000).

Vitamin A mempunyai provitamin yaitu karoten. Pada sayuran vitamin A terdapat sebagai provitamin dalam bentuk pigmen berwarna kuning B karoten (Murray, 2000). Vitamin A telah dipakai untuk pengobatan penyakit kulit seperti jerawat, tetapi dosis yang berlebihan dapat bersifat toksik (Sulistia,1995).

Kelebihan vitamin A selama kehamilan (> $6000 \mathrm{IU}$ ) dapat menimbulkan efek teratogenik pada janin (Joyce,1995). Kelebihan pemakaian vitamin A harus dihindari karena vitamin ini bersifat hanya larut dalam lemak dan disimpan

di dalam hati, serta lambat diekskresikan dari tubuh. Vitamin A diekskresikan melalui ginjal dan feses (Murray, 2000).

Pemakaian bahan kimia pada ibu hamil trimester pertama banyak menyebabkan kecacatan, dikarenakan dalam masa ini 
terjadi proses organogenesis, sehingga mengakibatkan embrio sangat rentan terhadap efek teratogenik, mengakibatkan kelainan tergantung pada organ yang paling peka terhadap zat teratogen yang diberikan (Lu, 1995).

Vitamin A yang berlebih akan terakumulasi dalam tubuh, karena vitamin A akan ditimbun dalam jaringan hingga dapat meracuni tubuh dan menimbulkan kelainan pada perkembangan anggota tubuh (Solihin, 2000 dalam Riami, 2005). Beberapa penelitian menggambarkan adanya kelainan pada fetus mencit yang induknya diinduksi vitamin A. Pemberian asam retinoat menyebabkan kelainan anggota seperti polidactyly, micromelia, ectrodactyly, syndactyly, club foot (Kwasigroch ,1991).

Asam retinoat yang diberikan pada umur kebuntingan 9,5 hari, menyebabkan hipodactyly yang mengarah pada gangguan pola asimetris jari, jari pertama panjang dan polidactyly yang asimetris ( Niederreither, 2002). Pemberian asam retinoat pada dosis 75 dan $100 \mathrm{mg} / \mathrm{kg}$ berat badan tidak 100\% berpengaruh terhadap perkembangan fetus mencit, karena ada beberapa yang mengalami kelainan (Yulia, 2004).

Pemberian asam retinoat pada mencit bunting umur kebuntingan 11 hari dengan dosis $30 \mathrm{mg} / \mathrm{Kg}$ berat badan terjadi kelainan ukuran tulang, sedangkan dampak maksimum dan total kecacatan janin adalah dosis $60 \mathrm{mg} / \mathrm{Kg}$ berat badan atau lebih tinggi. Insiden pada celah palatum meningkat yang disebabkan pemberian dosis maksimum $100 \mathrm{mg} / \mathrm{Kg}$ berat badan (Jerry, 2004), penelitian ini menggunakan asam retinoat dengan dosis tunggal $60 \mathrm{mg} / \mathrm{Kg}$ berat badan, pada dosis tersebut di harapkan mampu memberikan efek teratogenik. 
Umur kebuntingan 10 hari, merupakan masa organogenesis atau morfogenesis yaitu merupakan masa paling penting untuk perkembangan normal dari sebagian besar organ dan sistem organ. Kebuntingan hari ke-10 merupakan masa kritis organogenesis dari anggota tubuh, skeletal dan mata (Rugh, 1968). 


\section{BAB 2 \\ TINJAUAN UMUM \\ ASAM RETINOAT}

\section{A. Asam Retinoat}

Vitamin A adalah salah satu vitamin yang larut dalam lemak, merupakan suatu molekul apolar hidrofobik yaitu berupa senyawa polyisoprenoid yang mengandung cincin sikloheksional, hampir tidak berwarna, tidak larut dalam air, larut dalam lemak dan pelarut lemak. Molekul ini tidak dapat disintesis oleh tubuh dalam jumlah yang memadai sehingga harus dipasok dari makanan (Murray, 2000).

Pemasokan vitamin yang larut lemak memerlukan penyerapan lemak yang normal agar vitamin tersebut dapat diserap dengan efisien. Setelah diserap, molekul vitamin tersebut harus diangkut dalam darah seperti halnya lipid apolar yang lain, di dalam lipoprotein atau protein pengikat yang spesifik (Joyce, 1995).

Vitamin A bisa ditemukan sebagai alkohol (retinol), sebagai aldehid (retinal), dan sebagai acid (asam retinoat) pada bentuk bebas setelah mengalami esterifikasi dengan asam lemak contohnya sebagai vitamin A palmitat (Church, 1988). $\beta$-karoten merupakan provitamin A, yang dapat membentuk 2 molekul vitamin A, ditemukan pada semua bagian tanaman yang hijau dan sebagian besar berwarna kuning, terdapat dalam sejenis kol, bayam dan wortel (Mutschler, 1991).

Retinol yaitu alkohol primer 20 karbon yang terdapat pada berbagai bentuk isomer, sebagian besar berasal dari makanan terdapat dalam bentuk ester. Retinal berasal dari karotenoid yang diserap dari makanan atau ester-ester retinol dan memiliki aktivitas vitamin A.

Asam retinoat, derivat oksidasi dari retinol yang dibentuk melalui karboksilasi terhadap gugus aldehid retinal, zat ini diyakini merupakan bentuk vitamin A yang berperan dalam 
perkembangan dan pertumbuhan tulang serta pemeliharaan struktur normal epitel (Almatzier, 2003).

Retinol dan retinal dapat saling berubah oleh perubahan nicotinamide adenine dinucleotida (NAD) atau nicotinamide adenine dinucleotida phosphate (NADP) dan membutuhkan dehydrogenase atau reduktase. Tetapi bentuk dari retinoid yaitu asam retinoat tidak dapat berubah kembali ke bentuk retinal atau retinol (Almatzier, 2003; Dorland, 2002).

Asam retinoat mempunyai beberapa macam struktur dengan kemampuan teratogenik yang berbeda-beda, dapat berupa asam retinoat alami maupun sintetik. Retinol setelah terikat dengan protein akan diangkut ke dalam sel dan terikat pada protein nukleus, retinol mungkin terlibat dalam pengendalian ekspresi gen tertentu. Sumber retinoid yang alami untuk jaringan embrionik adalah retinol maternal. Berdasarkan struktur kimianya terdapat enam tipe asam retinoat yang mengikat protein nukleus, yaitu tiga ikatan all-trans asam retinoat meliputi 4-hidroksi-retinol, 4-okso-retinol, dan 14-hidroksi4, 14-retro-retinol dan tiga mengikat 9-cis asam retinoat meliputi 4-hidroksi-RA, 4-okso-RA, 3,4-didehidro-RA (ddRA). Vitamin A merupakan reseptor kompleks termasuk all-trans asam retinoat merangsang transkripsi beberapa gen spesifik, dan rangsangan ini diperkuat oleh kompleks yang melibatkan 9-cis asam retinoat. Pengikat alami bagi all-trans asam retinoat adalah retinoic acid receptors (RAR) dan 9-cis asam retinoat adalah retinoid $X$ receptors (RXR) (Ross, 2000).

Vitamin A juga menyebabkan perubahan dalam metabolisme pengaturan genetik. Perubahan ini melibatkan pembentukkan glikoprotein (Broody, 1994 dalam Kiptiyah, 2002). 
Struktur kimia Retinoid seperti gambar di bawah ini :

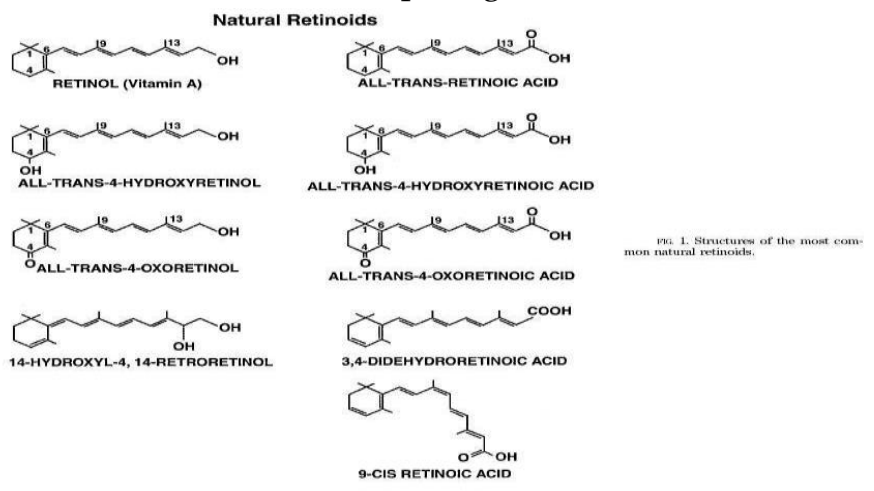

Gambar 2.1 Struktur Kimia Vitamin A Dan Derivatnya (Ross, 2000)

Kebutuhan vitamin A, khususnya pada hewan coba mencit untuk makanan alam bahan formula adalah $15.000 \mathrm{IU} / \mathrm{Kg}$ BB, dari makanan murni 1.100 - 4.000 IU/Kg BB, dan dari serapan bahan kimia 1.730 IU/Kg BB (Jacoby, 1984 dalam Riami, 2005). Kebutuhan vitamin A sehari-hari pada manusia adalah 1.000 4.000 IU bagi anak-anak, 4.000 - 5.000 IU bagi orang dewasa, dan 5.000 - 6.000 IU pada wanita hamil dan laktasi. WHO menganjurkan maksimal 8.000 IU sehari bagi wanita hamil, jika dikonversi 20,8 IU/20g/hari angka konversi tersebut diperoleh dosis minimal asam retinoat untuk mencit (20) $g=0,0026$, karena pada dosis tinggi (25.000 IU sehari atau lebih) dapat meningkatkan resiko teratogen atau cacat pada janin (Tjay, 2003 dalam Riami, 2005 ).

Toksisitas dari vitamin A tergantung pada umur pemberian, dosis, lama pemberian, walaupun toksisitas vitamin A tidak umum ditemukan terjadi pada orang dewasa yang mengkonsumsi $<30 \mathrm{mg} / \mathrm{hr}$. Gejala toksisitas yang ringan dapat dideteksi pada orang dewasa yang mengkonsumsi $10 \mathrm{mg} / \mathrm{hr}$ selama 6 bulan. Terjadi toksisitas akut pada pemakaian $\geq 500 \mathrm{mg}$ untuk orang dewasa, $\geq 100 \mathrm{mg}$ pada anak, $\geq 30 \mathrm{mg}$ pada bayi sering menimbulkan keracunan. Pada anak dan bayi pemakaian 
20.000 IU atau $6 \mathrm{mg}$ setiap hari selama 1-2 bulan menyebabkan toksis (Goodman, 2001).

Pemberian asam retinoat pada mencit bunting umur kebuntingan 11 hari dengan dosis $30 \mathrm{mg} / \mathrm{Kg}$ berat badan terjadi kelainan ukuran tulang, sedangkan dampak maksimum dan total kecacatan janin adalah dosis $60 \mathrm{mg} / \mathrm{Kg}$ berat badan atau lebih tinggi. Insiden pada pembelahan palatum meningkat yang disebabkan pemberian dosis maksimum $100 \mathrm{mg} / \mathrm{Kg}$ berat badan (Jerry, 2004).

Diketahui pula bahwa vitamin A berperan dalam sintesis beberapa hormon steroid. Terdapat sejumlah hormon steroid yang dipengaruhi vitamin A, khususnya pada masa kehamilan dan juga gangguan proses pengaturan keseimbangan garam dan cairan tubuh (Sediaoetama, 2000).

Asam retinoat yang berasal dari vitamin A, berfungsi seperti hormon steroid. Hormon steroid ini mendorong pertumbuhan dan diferensiasi jaringan epitel, mengoptimalkan pertumbuhan tulang, dan meningkatkan perkembangan janin. Oleh sebab itu, tubuh memerlukan asupan makanan yang mengandung vitamin A dari luar. Hal ini dikarenakan, tubuh tidak dapat memproduksi vitamin A secara langsung (Wendling, 2001).

Hormon steroid ini berikatan dengan reseptor di inti sel sasaran, dan kompleks reseptor asam retinoat berikatan dengan elemen respon di DNA kemudian mempengaruhi transkripsi gen (Coskun,1998). Reseptor bagi asam retinoat termasuk dalam reseptor steroid. Protein yang dihasilkan oleh ekspresi gen diaktifkan oleh asam retinoat dan berperan menimbulkan efek vitamin A pada pertumbuhan, differensiasi, reproduksi dan perkembangan janin (Marks, 1996). Pada penelitian ini menggunakan asam retinoat karena derivat vitamin A yang lain sudah banyak yang meneliti dan all-trans asam retinoat di duga memiliki potensi teratogen lebih besar di bandingkan dengan 13cis asam retinoat (Kochhar, 1995).

Asam retinoat ini merupakan metabolit normal vitamin A untuk menjaga kesehatan dan membantu pertumbuhan yang 
dibutuhkan dalam jumlah sedang pada pembentukkan bentuk aktif. Asam retinoat dalam tubuh manusia akan diekskresikan lebih banyak melalui empedu dari pada melalui urine. Sedangkan pada tikus, hanya sedikit sekali yang diekskresikan melalui empedu (Prakkasi, 1992).

\section{Absorpsi, Transportasi dan Metabolisme Asam Retinoat}

Bentuk awal vitamin A dalam makanan adalah retinil ester yang dikeluarkan oleh sel mukosa usus pada inti hidrofobik dari partikel kilomikron, akan tetapi sebelum direabsorpsi retinil ester tersebut dihidrolisis dahulu menjadi bentuk alkohol. Retinol ini akan memasuki dinding usus untuk kemudian diubah lagi menjadi retinil ester sebelum memasuki pembuluh limfe dan disalurkan ke hepar untuk disimpan. Vitamin A dibawa ke hepar setelah melalui sirkulasi limfatik, dan akhirnya masuk ke plasma setelah melewati duktus toratikus. Vitamin A juga dapat diabsorpsi melalui jalan non limfatik (Combs, 1992). Sementara retinol dan retinil ester ditranspor melalui sistem limfatik sebagai komponen kilomikrom, asam Retinoat ditranspor ke dalam sirkulasi umum melalui vena porta, dalam bentuk anion karboksilat yang terikat pada serum albumin. Asam Retinoat yang terbentuk in vivo mengikuti jalur yang sama dengan asam Retinoat yang diberikan per oral. Asam retinoat di transportasikan dalam serum tikus terikat dengan serum albumin dan bukannya protein terikat retinol (RBP - Retinol Binding Protein). Ada kemungkinan bahwa analog Asam Retinoat (a-Asam Retinoat, RO 8-7699) juga beredar terikat pada serum albumin (Jerry, 2004).

Retinil ester yang baru diabsorpsi segera dibawa memasuki hepar bergabung dengan sisa kilomikron oleh receptor mediated secara endositosis (pengambilan bahan dari lingkungan oleh sebuah sel melalui invaginasi membran plasmanya, proses ini mencakup fagositosis dan pinositosis) pada sel perenkim hepar. Retinil ester yang diterima terhidrolisis menghasilkan retinol. Retinol ini dapat ditransfer dari sel parenkim ke sel stelate dimana retinol mengalami 
reesterifikasi. Diperkirakan 90 - $95 \%$ persediaan vitamin A dalam tubuh terdapat dalam bentuk retinil ester dalam sel Kupffer hepar. Ginjal, anak ginjal, testis dan payudara juga mengandung vitamin A (Pudjiadi, 2000).

Menurut Combs, 1992 vitamin A dalam tubuh $80 \%$ disimpan di dalam sel stelata ( sekitar $2 \%$ dari total volume hati) dan dalam keadaan seimbang di dalam sel parenkim. Hampir semua vitamin A hepatik dalam bentuk rantai panjang Retinil ester, sedang yang bersifat predominan menjadi satu retinal palmitat.

Dalam hati, vitamin A disimpan dalam bentuk ester dalam liposit (sel stelata/perisinusoidal), yang mungkin sebagai suatu kompleks lipoglikoprotein (Murray, 2000).

Vitamin A dimobilisasi dari penyimpanannya di hepar sebagai ester pada sel liposit (Perisinusoidal Stellate Cells) mungkin sebagai lipoglikoprotein kompleks. Selama transportasi ke jaringan, retinil ester terhidrolisis dan retinol, kemudian dilepas ke dalam darah dengan terikat pada protein pengikat yaitu Apo-retinol Binding Protein (RBP), menghasilkan holo-RBP sebagai proses dalam Aparatus Golgi dan sisa dalam plasma. Retinil ester terbawa ke jaringan melalui reseptor yang terletak pada asam retinoat dan dibawa ke plasma setelah terikat pada albumin. RBP atau a1- globulin ini terdiri dari ikatan tunggal polipeptida, RBP memiliki tempat ikatan tunggal untuk retinol (Combs,1992). Bagian dalam sel ekstrahepatik retinol terikat oleh Celluler Retinol Binding Protein (CRBP) (Mayor, 2000).

Protein yang spesifik mengikat retinol seluler yaitu cellular retinol-binding protein (CRBP), Pada jaringan Celluler retinol Binding Protein (CRBP) mengikat retinol dan mengatur metabolisme vitamin A di dalam sel.

Fungsi CRBP adalah untuk mengkonsentrasi dan menyimpan retinol di tempat yang membutuhkan asam retinoat dalam konsentrasi yang relatif tinggi, sehingga retinol dapat diubah menjadi asam retinoat untuk proses morfogenetik. Sedangkan untuk asam retinoat membutuhkan 
cellular retinoic acid binding protein (CRABP) dengan afinitas yang tinggi (Ong dan Chytilo 1978), Cellular retinoic acid binding protein (CRABP), ditemukan di dalam sitoplasma fungsi dari protein sitoplasmik ini masih tidak jelas, dimana tidak didapatkan protein yang serupa pada mekanisme kerja dari hormon steroid / thyroid, protein tersebut mungkin terlibat di dalam metabolisme retinoid yang diduga protein tersebut menunjukkan populasi sel yang responsif terhadap asam retinoat (Maden, 1991), dan mungkin bertanggungjawab di dalam pengaturan konsentrasi intrasel retinoid bebas, misalnya untuk menimbulkan gradien konsentrasi asam retinoat bebas (Smith, 1988).

Asam retinoat bebas yang terikat pada CRABP akan mempertahankan kadar asam retinoat aktif tetap pada kadar yang rendah, juga berguna untuk asam retinoat bebas yang terbentuk melalui pelepasan dari sel yang mengandung CRBP.

Kelch (1994) melaporkan bahwa sirkulasi RBP di dalam darah, transport retinol ke sel target tidak masuk ke jaringan. RBP ditemukan dalam 2 bentuk yaitu, Apo-RBP adalah bentuk bebas, dan Holo-RBP yang mengikat vitamin A, dan sirkulasi di dalam kompleks molar dengan prealbumin. Produk ini diambil oleh jaringan lewat reseptor sel permukaan. RBP dikatalisis dan diatur oleh ginjal setelah pengambilan retinol ke dalam sel. Retinol diatur melalui ekskresi fekal dan sejumlah kecil keluar melalui urine.

Asam retinoat diangkut di dalam plasma dalam keadaan terikat dengan albumin. Begitu berada di dalam sel ekstrahepatik, retinol akan terikat dengan protein pengikat retinol. Protein yang mengikat retinoid merupakan kelompok makromolekul yang mempunyai peranan sangat khusus bagi proses molekular dalam sel. Protein pengikat retinol merupakan polimer asam amino (polipeptida) yang mempunyai bermacam-macam fungsi, antara lain: sebagai katalisator reaksi biokimia dalam sel, pengangkut molekulmolekul kecil dan ion, berperan di dalam sistem pergerakkan yang terkoordinasi, komponen sistem kekebalan tubuh, 
feromon, penerus impuls saraf, komponen pendukung kekuatan-regang serta pengatur ekspresi genetik (Yuwono, 2005).

Transportasi vitamin A di dalam darah dan sel (Robert, 1994), terjadi sebagai berikut :

a. Retinol dilepaskan dari hati kemudian berikatan dengan retinol binding protein (RBP). Pada plasma spesifik $\mathrm{Zn}$ dan pemberian protein yang cukup diperlukan untuk menghasilkan RBP. Retinol dan RBP bergabung dengan Trans-Thyretin (TTR, juga mengikat tiroksin) di dalam sirkulasi darah dengan perbandingan 1:1:1 kompleks trimolekuler.

b. Pada kelompok plasma normal retinol dipertahankan hingga vitamin A yang disimpan di dalam hepar habis.

c. Retinol RBP kompleks diambil oleh sel pada saat retinol berikatan dengan Celluler retinol Binding Protein (CRBP). Retinol dimasukkan ke dalam asam retinoat yang mengikat Retinoic Acid Receptor (dinamakan RAR dan RXR).

Retinoic Acid Receptor (RAR) mengikat asam retinoat dan mengatur ekspresi gen. Ikatan komplek berinteraksi dengan DNA, dan mengatur transkripsi menjadi RNA Asam retinoat telah melakukan feed back mechanisme, pada saat terjadi peningkatan kelompok-kelompok asam retinoat, sehingga aktivitas LRAT (Lecithin Retinol Acyl Transferase) meningkat, LRAT disimpan di dalam hati (Kelch,1994).

Metabolisme vitamin larut lemak sangat lambat, sehingga dosis berlebihan dapat menimbulkan efek toksik (Dewoto, 2003). Metabolisme vitamin A terpusat disekitar transportasi dari retinol dengan berbagai cara konversi meliputi esterifikasi, konjugasi, oksidasi dan isomerasi. Retinol diesterifikasi pada sel usus dan pada sebagian besar jaringan lainnya melalui enzim endoplasmik retikulum dengan menggunakan kelompok acyl dari fosfatidilkolin atau Lecithin-Retinol Acyl-Transferase (LRAT) atau acyl- coenzym A Retinol Transacylase (ARAT). Pada sistem ini terlihat tanda spesifik untuk asam lemak jenuh khususnya asam palmitat, 
yang kemudian menghasilkan retinil palmitat dalam jumlah yang banyak (Combs, 1992).

Retinol kemungkinan terkonjugasi dari salah satu cara ini, yaitu pertama melalui reaksi katalis oleh Retinol-UDPGlukonidase yang ada dihati atau mungkin pada jaringan lain. Reaksi ini menghasilkan retinil beta Glukorinida yaitu suatu metabolit yang diekskresi dalam empedu. Kedua, melalui konjugasi ATP yang tergantung pada fosforilasi, menghasilkan retinil phosphat yang dikatalisis oleh retinol-phosphorilase. Pada konjugasi ini dihasilkan guanosin diphosphomanose yang telah diubah menjadi glikosida retinil phosphomanose, yang kemudian akan dibawa ke reseptor-reseptor glikoprotein. Retinol yang dihasilkan melalui fosforilase secara in vivo jumlahnya sedikit. Secara fisiologis, reaksi melalui jalur ini belum diketahui dengan jelas (Combs, 1992).

Retinol dioksidasi kembali oleh NADH+ atau NADPH menjadi retinal tergantung pada retinol dehidrogenase. Reaksi ini bisa terjadi pada jaringan lain tapi yang terbesar terjadi pada testis. Retinol bersifat irreversibel setelah mengalami oksidasi oleh retinol oksidase menghasilkan asam retinoat. Asam retinoat dioksidasi menjadi 4-oxo all-trans oleh enzim cytochrome P 450 dependent. Enzim ini sangat penting karena enzim ini yang bertanggung jawab atas aktivasi metabolik untuk zat prokarsinogen dan terdapat dalam retikulum endoplasma (Murray, 2000). Oksidasi retinol menjadi retinaldehida membutuhkan NAD+ dan bersifat bolak-balik, langkah berikutnya menjadi asam retinoat tidak reversibel dalam jaringan hewan. Oleh karena itu hanya konsumsi retinol dan retinal yang dapat menghasilkan penyimpanan vitamin (Linder,1992).

Rentangan reaksi ini pada umumnya lebih besar pada retinol dehidrogenase, dengan rentangan reduksi retinal menjadi retinol yang sangat rendah (Combs, 1992). 


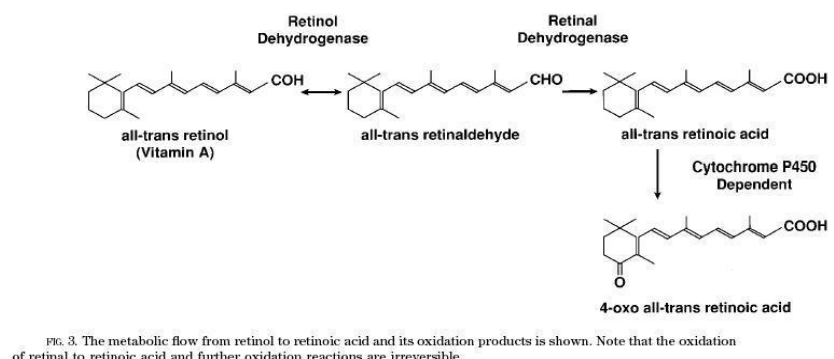

Gambar 2.2 Aliran Metabolisme Dari Retinol Ke Asam Retinoat Dan Oksidasinya. (Ross, 2000)

Retinol dan retinal dapat melakukan interkonversi dengan adanya enzim dehidrogenase atau reduktase yang memerlukan NAD atau NADP di dalam banyak jaringan. Namun demikian, begitu terbentuk dari retinal, asam retinoat tidak dapat diubah kembali menjadi retinal atau retinol. Jadi asam retinoat dapat mendukung pertumbuhan dan diferensiasi, tetapi tidak dapat menggantikan retinal dalam peranannya pada penglihatan ataupun retinol dalam dukungannya pada sistem reproduksi.

Asam retinoat meregulasi perkembangan dengan mengaktivasi transkripsi gen pada banyak lokasi yang berbeda dalam embrio. Suatu sel tertentu hanya akan merespons asam retinoat jika (Ross, 2000) :

1) ia mengekspresikan reseptor asam retinoat.

2) konsentrasi asam retinoat berada dalam rentang yang sesuai bagi responsnya.

Ada dua model kerja asam retinoat dalam tubuh. Selain protein RAR yang berperan sebagai faktor transkripsi di inti sel, terdapat juga protein sitoplasmik yang mengikat retinoid. Salah satunya, cellular retinol binding protein (CRBP1) terdapat pada yolk sac, yang mengikat retinol dari sirkulasi ibu (Ruberte, 1991). 